that in the Baltic, where tidal movements are very small, the wind current, as the wind abates, gradually degenerates into a circular, or rather a spiral, movement of decreasing amplitude, the diameter of the paths of the water-particles varying from some 3 kilometres downwards. It appears likely, that similar 'inertia currents' are also to be found in the sea, at least where the tidal movements are not too strong to obscure them completely. An examination of current-records from the west coast of Sweden is being undertaken with this purpose.

\section{TORSTEN GUSTAFson.}

Bornö Station.

BörJE KULLFNBERG.

Feb. 8.

Factors Controlling Date of Spawning in Frogs

In Nature of April 8, p. 521, reference is made to the factors which determine the time of spawning of the common frog, Rana temporaria.

Through the courtesy of the Royal Meteorological Society, I have been enabled to utilise the voluminous data contained in the Society's Phenological Reports for the investigation of this matter. The results, it is hoped, will shortly be ready for publication, but since the matter has now been raised, it may be of interest to state briefly that frogs are scarcely at all affected by the weather at the time of spawning, or that immediately preceding, but there is a close relation between the mean temperature over a long period prior to spawning and the mean date of spawning in a district. For example, within fifty miles of London, only a few cases of spawning usually occur in February, and March is the usual spawning month, most reports being about the middle of the month. I have calculated a correlation co-efficient of -0.77 between the mean temperature at Kew for February and the mean spawn date for the area. The effect of March temperature is perceptible if one employs a weighted mean, allowing for the distribution of the spawn dates over the period, but it is much smaller. The only important effect of the weather at the time of spawning seems to be the break in the normal sequence of spawning caused by a very cold 'snap'.

$$
\text { R. Maxwell Savage. }
$$

19 Derwent Avenue,

London, N.W.7.

\section{Early History of the British Solomon Islands}

Several references were made in the Calendar of Geographical Exploration published in NATURE last year to the Solomon Islands, and the following notes on their early history may be of interest.

The Solomon Islands lie some five hundred miles east of New Guinea and were discovered on a voyage from Callao, Peru, in 1568 by the Spaniard, de Mendaña. After naming most of the larger islands during a six months' cruise, the two frigates returned to South America.

Mendaña named the islands after King Solomon with the idea of attracting colonists to search for gold and treasure. However, it was not until thirty years later that a second expedition of four ships set sail but failed to find the Solomons proper, arriving instead at Santa Cruz Island to the east, where a brief settlement was made until Mendaña's death in October 1595. The survivors (only three ships arrived) under the Portuguese navigating officer de Quiros made an attempt to reach San Cristobal, previously discovered in 1568. Not only were they unsuccessful in locating it, but they also failed to strike any land before the Philippines, whence they sailed for Peru.

For nearly two centuries nothing was known of the Solomons until Capt. Carteret in the Swallow rediscovered Santa Cruz and Malaita in 1767, without however landing anywhere. Next year came the French navigator de Bougainville, followed by de Surville (1769), Maurelle (1781) and Shortland (1788).

The climax of eighteenth century navigation was the shipwreck of two frigates under La Perouse which reached Vanikoro, Santa Cruz, in 1788, but about which nothing was known for forty years until Dillon, in command of the East India Company's Research, found proof in 1827 of their fate.

By this time whalers and traders, the latter in search of bêche-de-mer, sandal wood and tortoiseshell, had already begun the nineteenth century commercial exploitation of the tropics.

\section{R. J.A. W. LEVER.}

Tulagi,

British Solomon Islands Protectorate, Jan. 20.

\section{A New Alloy, 'Stainless-Invar'}

INVAR, invented by Ch. Ed. Guillaume in 1896, has a small coefficient of thermal expansion, about $1 \cdot 2 \times 10^{-6}$. Since then, no better invar has been obtained. I have, for the last six years, been engaging in the investigation of alloys having a small coefficient of expansion and obtained in June, 1929, an alloy ${ }^{1}$ containing about 63.5 per cent iron, 31.5 per cent nickel and .5 per cent cobalt, which has a smaller coefficient of expansion than that of fused silica.

Several explanations of the small expansibility of invar have been proposed, but none can be considered to be satisfactory. I also tried to explain this phenomenon and developed a new theory ${ }^{1}$ by which the small expansibility of invar can be satisfactorily explained from magnetic data. Following up this theory, I began to investigate the thermal expansion of the ternary alloys of iron-cobalt-chromium and found that an addition of a small quantity of chromium to iron-cobalt alloys containing more than 50 per cent cobalt considerably reduces their expansibility. In July, 1931, I obtained an alloy having a much smaller coefficient of expansion than that of fused silica. For example, the coefficient of linear expansion at ordinary temperature of an alloy containing about $36 \cdot 5$ per cent iron, $54 \cdot 5$ per cent cobalt and 9 per cent chromium is less than $10^{-7}$ in the annealed state, and that of another alloy having a very similar composition to the above has even a negative coefficient amounting to $-1.2 \times 10^{-6}$. These alloys are so resistant to corrosion that polished surfaces can be left for several months in a moist atmosphere, water, sea water, etc., without showing any rust spots; they have been called 'stainlessinvar' (Hakar Masumoto).

\footnotetext{
Research Institute for Iron, Steel and Other Metals, Sendai, Japan. March 10.
}

${ }^{1}$ Sci. Rep. Tôhoku Imp. Univ., 20, 101; 1931.
KôTARô HONDA. 